\title{
THE COORDINATES OF CO-PRODUCTION IN THE EDUCATIONAL SERVICES SYSTEM
}

\author{
Alexandru JIVAN ${ }^{1}$, Maria BARABAS 2
}

DOI: 10.1515/tjeb-2017-0003

The paper proposes a certain delimitation of the concepts of cooperation and co-production in services and aims to apply them concretely in education, related to the connections (cooperation) between offeror and beneficiary. The article is part of a wider plan that seeks to implement the legitimacy of using the notion of coproduction in all sectors of activity, whether it is the one of goods or services to designate cooperative relationships between producer and consumer or, as we like to say, between the offeror and the beneficiary. The article starts with the definition and clarification of the concept of coproduction. After briefly setting several conceptual aspects, an applied analysis is performed on a group of respondents from education, using a questionnaire developed to provide adequate information for the purposes set forth: some relationships between the influence factors of the co-production between teacher and student are analysed. The questionnaire allows us to share interesting conclusions regarding the reasons that make people to participate. An analysis of the logic behind the co-production phenomenon is offered, reserves for the improvement of such relations being revealed for the education system. The conclusions following the data analysis confirm the initial assumptions and reveal interesting aspects, as described in the final section.

\section{Keywords: $\quad$ Co-production, Educational Services, Reciprocal Adjustment \\ JEL Classification: A13, A20, C81}

\footnotetext{
${ }^{1}$ Professor PhD, West University of Timisoara, Faculty of Economics and Business Administration, Romania.

2 PhD Student, West University of Timisoara, Faculty of Economics and Business Administration, Romania.
} 


\section{Introduction}

The problem of producing value with the beneficiary (co-production) is a topic which, in recent decades, has been in the attention of specialists in service economy.

Since the consumer has no automatism for co-production, this is one of the reasons as to why currently there is an area of research of potential triggers that have the capacity to enhance the decision to co-produce. According to the dictionary, work is the conscious activity, specific to humans, directed to a specific purpose, during which man makes, regulates and controls by his action the exchange of materials between him and nature to meet his needs. Co-production is also a conscious decision, of the producer and of the consumer, to engage in a joint activity, with a certain purpose, during which to exchange information and resources to meet the needs. From the definitions given by those who have studied the issue, it appears that the producer, as a general rule, is open to co-production, and the one who expects positive response is the consumer.

The distinctive character of our approach lies in (1) detailing the contents of co-production, in the sense of studying it more thoroughly as a process and as effects, and in (2) nuancing that delineates the meaning of these two terms: cooperation in education and, more applied, co-production in training/education.

The empirical research based on samples leads to relevant conclusions on the joint action between the provider (teacher) and beneficiaries (students), especially in terms of reciprocal adjustment of activity, conclusions that correspond to expectations. The data collected through the questionnaire and their analysis allowed us to compare cooperation with coproduction and distinguish between their operational possibilities.

The paper is organized as follows: the coordinates of co-production, with some delimitations are presented in Section 2. Sections 3 describes the two terms: cooperation versus coproduction, in the educational context. Section 4 contains the methodology involved and the assumptions that we intend to verify. The verification of hypotheses is presented in Section 5. Section 6 includes the limitations of the study. Section 7 provides the conclusions and future works.

DE GRUYTER OPEN
Timisoara Journal of Economics and Business | ISSN: 2286-0991 | www.tjeb.ro Year 2017 | Volume 10 | Issue 1 | Pages: 35-50 


\section{Coordinates of co-production. Some delimitations}

Co-production is a notion that has shaped a unique meaning for itself. Discussed as a phenomenon in the goods sector, but also specifically relevant in the services sector especially due to their specificity of having as a necessary condition the presence of the client at the time and, more often, at the place of the provision -, co-production defines in this sense the beneficiary's involvement in activities which, traditionally, only fell on the producer. The correct phrase is "co-production between producers and consumers" or "co-production between offeror and beneficiary".

Co-production involves cooperation; but, compared to cooperation - which is a way of action - co-production is in itself a process that follows specific stages (as a "production" process, but, in our case, with elements specific to learning/education), a process that, after its completion, must lead to added utility. This result, the newly created added value, for education, consists of training (additional to previous states of each point in the process or formative stage in part), is represented by the level of education (superior to the initial one): this is the stake of education performance and of all processes related to the education system. The intended effect of the educational process consists of specific complex knowledge aspects, view of life and conduct. This formative "charge" (accumulation) general, conceptual and applied knowledge - is generated together (by cooperation), meaning that the educational contribution is a "co-product" based on planned activities in an organisation (including management of working time, individually and in groups, related to each activity, each concrete objective, immediate or on the long-run, bringing and using together the resources of the offeror and of the beneficiary), all found in learning; cooperation is also used to achieve the assessment component of the educational process, as an element necessary to understand the level achieved based on clear, fair, consistent principles, adequate to various aspects and circumstances, and therefore an element of "feedback", allowing the review of previous work to get closer to desired standards, thus for building the future. Planning falls on the same lines, through collaborative planning of objectives and establishing jointly an effective way to achieve goals. Co-production in education is achieved by the reciprocal adjustment that takes place in cooperation and by adapting, over time, the expectations, conditions, actions and values of the parties. The key components of coproduction therefore are: participation, working together, cooperation, reciprocal adjustment.

These components are achieved jointly, even if the parties (provider and beneficiary) have specialised roles, meaning that most often - though not always - the initiative comes from the teacher, and the final decision (for example, in case of a "divergence" in terms of the assessment) belongs to him or her, but documented and justified.

DE GRUYTER OPEN

Timisoara Journal of Economics and Business | ISSN: 2286-0991 | www.tjeb.ro Year 2017 | Volume 10 | Issue 1 | Pages: 35-50 
Jivan, A., \& Barabas, M. (2017).

The coordinates of co-production in the educational services system

According to the above, co-production in education involves co-involvement, co-planning, comanagement of time, co-learning, co-assessment, and reciprocal adjustment. Beneficiaries will have a predilection for one or other of the stages, as can be seen from the results of the survey conducted in three representative high schools from three different counties in the country. Co-production in education involves achieving (together), to a greater or lesser extent, all of these stages. For co-production to exist, the student must be involved, together with the teacher, in the teaching-learning activity, must manage time with the teacher, learn by taking part in the lesson, while continuing to exercise at home, assess and self-assess before the teacher grades, thus allowing for a so-called "reciprocal adjustment" (Schultze \& Bhappu, 2006), which includes enrichment of thought and conduct modification.

Currently, the view on the role of the student has evolved from that of mere beneficiary of imparted knowledge to that of active participant in achieving knowledge. Although the image of the student as participant originated in the Antiquity that promoted dialogue, when the discovery of truth took place by causing the interlocutor to find answers sought in his own questions, the novelty of the interaction lies in the new information networks, in communication technologies and globalisation, which led to radical changes. In the organisation of education, more than in any other organisation, offerors and beneficiaries are active human resources in a process of cooperation. Cooperation becomes co-production when results occur, when the "production" of knowledge and of the other components of education are efficient, "materialised" in forming the beneficiary of the educational process, i.e., when it can be said that reciprocal adjustment had determined changes in the thinking, view of life and conduct of the beneficiary by the modelling effect given by the individualised reporting of the offeror to each subject. This is due both to the reality that services are always associated with a relational function, in which cooperation is inevitably present, and especially to the role of education, with its specific objective consisting of the positive transformation of the individual. In this context, we also keep in sight the transformations that occur on the very educational service provider, as an individual participating in the process of that "co-production".

Co-production, particularly from a consumer perspective, is a choice, subject to resource constraints. Incorporating clients' time is very important, given the fact that the human individual always tries to combine time and other resources to obtain the greatest utility possible. Gary Becker noted that "combining production and consumption is at odds with the tendency of economists to separate them clearly, production occurring in companies, and consumption in households" (Becker, 1998). Including the consumer in one of the links of the offeror's goods or services production chain is, however, considered by entrepreneurs and in economics - as a modern way to diversify the forms of action in competitive economy.

The trend towards increased end client involvement in co-production is primarily the result of the radical changes that have occurred in the technological development and that have

\section{DE GRUYTER OPEN}

Timisoara Journal of Economics and Business | ISSN: 2286-0991 | www.tjeb.ro Year 2017 | Volume 10 | Issue 1 | Pages: 35-50 
Jivan, A., \& Barabas, M. (2017).

The coordinates of co-production in the educational services system

helped refine consumer tastes due to the explosion of information and the free and almost instantaneous access to texts and images. Clients today are active or, as Bettencourt stated, are "partners in the production process" (Bettencourt, 1997). Well, before receiving the final goods or services from the offeror/provider, they determine them as form and content. The "conversion" of clients into co-producers first requires exploring their talents and skills and their orientation to business needs (Bendapudi \& Leone, 2003).

Rodie and Kleine (2000) defined co-production as being represented by the actions and resources of clients, used in various stages of production and delivery.

According to Baqer (Baqer, 2006), "co-production is a continuous and dynamic exchange between the company and clients, in order to turn the latter into active participants in every step of the production process by maintaining their affective and cognitive involvement".

According to the literature research, the concept of co-production has been associated sometimes with the cooperation between public services and citizens, as consumers of these services. Whitaker stated (Whitaker, 1980) that co-production describes "citizen participation in public service delivery".

Dabholkar, in 1990, noted: "co-production means the mental and physical participation of the consumer in the processes of production and delivery" (Dabholkar, 1990).

Most often, however, co-production represents the mutual use of resources, regardless of the economic, public or private environment, in order and with the purpose to obtain better results.

We shall not go into further details and conceptual delimitations found in the literature, as, for example, the distinction between co-production and co-creation (Andreassen, Gustafsson, Gebauer, 2010) or the creation of value in consumption versus production.

The elements describing co-production provide a complex image. Although economists who have discussed this issue cannot state that there is a single formula to define it, some key characteristics included in the idea of co-production can be highlighted:

- persons who use services are considered assets of the company, with skills and competencies that can be valued;

- persons who co-produce act together to accomplish their common goals;

- users and professional providers are equal partners, and this includes reciprocity; barriers existing between cooperating parties are, thus, eliminated.

\section{DE GRUYTER} OPEN
Timisoara Journal of Economics and Business | ISSN: 2286-0991 | www.tjeb.ro Year 2017 | Volume 10 | Issue 1 | Pages: 35-50 


\section{The educational context - cooperation versus co-production}

The education system operates on the educational supply and demand market. A good school will be ranked depending on the results of the students on the short-, medium- and long-term. Educational institutions whose graduates do not find suitable jobs or fail to be admitted to many faculties will face a lack of candidates, and vice versa. So, to operate, schools must sell their services. Educational marketing must take into account the fact that educational institutions have an intermediary role between the representatives of the demand for education existing at a time on the market and job providers, on the other hand.

In the case of educational services, their particularity of not always having a commercial nature does not also mean an essential differentiation from other services. Beneficiaries come with certain expectations, while offerors have, from the start, clearly defined objectives, translated in terms of student performance. Reaching common goals depends, to the greatest extent, on the physical and spiritual presence of beneficiaries and their contribution in carrying out each stage in good conditions. From the case study presented below, it can be seen that respondents understand "working together" as one of the specific attributes of cooperation "working together" not in the sense of "working together with" but in the sense of communication, mutual support, sharing knowledge, in order to achieve the educational goals planned). Cooperation and co-production are relational, the offeror and the beneficiary working together in creating value. According to Bateson and Goodwin (Bateson, 2000), the motivational factors of co-production include personality type, self-concept, which may include self-esteem, identity, values and beliefs, then preferences, commitment and competence. But cooperation stops at combining problems, interests and resources. Coproduction means reciprocal adjustment and change in the deep level of mentality, thinking, assimilation of knowledge, behaviour.

The projected objectives identified in the actual results of the educational process can be more easily achieved, if the beneficiaries participate in all the specific stages of teaching, learning and assessment.

The co-involvement of the beneficiary of educational services in teaching, learning and assessment depends, to a great extent, on the importance he attaches to the educational institution, in general, and to the subject, in particular. Although specific by the particularity mentioned above, educational services operate with market relations, and, ultimately, still relate to supply and demand. It is a kind of educational marketing, in which the education offeror promotes and sells his "product".

Co-planning refers to the participation of offerors and beneficiaries in the design of study topics, planning of activities and even teaching methods to be used. It is important for

\section{DE GRUYTER OPEN}


Jivan, A., \& Barabas, M. (2017).

The coordinates of co-production in the educational services system

beneficiaries of educational services to have clearly mapped responsibilities. Co-planning increases trust between offerors and beneficiaries, creating an environment favourable for professional communication.

Co-management of time admits that the most important external resource must be managed together by the offeror and the beneficiary. And not just the time spent during classes, but the individual time as well, which was not previously organised together. Taking into consideration time together, which is an individual resource, means efficient operation.

Co-learning depends largely on the ability of the teacher and the student's favourable disposition to listen and collaborate. It is a form of reciprocal adjustment, in which the offeror and the beneficiary of education base their actions by jointly considering problems. Colearning, therefore, means behavioural changes determined by communication and mutual changes of the expectations and actions of each party. Co-learning is the stage that depends to the greatest extent on the teacher's ability to deliver the educational services. Of course, one must not ignore the student's ability and willingness to listen to the teacher and participate actively in the learning process.

Co-assessment is a central activity of the educational process, providing the necessary information for self-adjustment and for formulating subsequent decisions. Co-assessment means:

- assessment of students by teachers;

- self-assessment, a self-evaluation process by which the student learns to know himself, with many implications on a motivational level;

- mutual assessment of students;

- assessment of teachers by students.

Co-assessment is considered one of the evaluation methods with extensive formative valences, allowing the assessment of the product and of the process from the inside, in which the beneficiary of educational services exercises his role of participant in his training.

Reciprocal adjustment is a phrase taken from Whitaker, who in 1980 defined co-production under three aspects: support, cooperation and reciprocal adjustment (Andreassen et al., 2010). Adapted to the education sector, reciprocal adjustment takes place through cooperation and mutual change of expectations, states and actions of the parties. In education, more than elsewhere, reciprocal adjustment is felt at high levels because the "product" that emerges from the process of production and co-production is knowledge, involving theoretical concepts, and conduct, behaviour, attitude.

DE GRUYTER OPEN
Timisoara Journal of Economics and Business | ISSN: 2286-0991 | www.tjeb.ro Year 2017 | Volume 10 | Issue 1 | Pages: 35-50 


\section{Methodology}

The research methodology involved the use of questionnaires, which required the development of a representative sample consisting of 77 respondents: the sample of beneficiaries of educational services. The questionnaire was addressed to students in the $12^{\text {th }}$ grade from the following educational institutions: "J. L. Calderon" Theoretical High School of Timişoara, "Traian Doda" National College of Caransebeş and the Dorna Candrenilor Technological High School, from Dorna Candrenilor, Suceava County. The decision to include exclusively final year high school students was made taking into account that they have the maturity, age, cognitive abilities and knowledge needed to grasp the connections of interest. The knowledge, abilities and skills of students in the final year of high school allow them to have a systematic and objective view on the topic in the questionnaire.

We used a specialised software for the analysis of quantitative data obtained: SPSS. Specifically, for the statistical analysis we used operations such as: Descriptive Statistics, Mean, Frequency Analysis, Pearson Correlation between the variables.

The research started with the following assumptions that we intended to verify:

I.: The cooperation between the offeror and the beneficiary of educational services is a prerequisite for co-production.

$\mathrm{I}_{2}$ : The co-production between the offeror and the beneficiary of educational services contributes to the long-term performance of the beneficiary.

$I_{3}$ : Organisational performance is dependent on the co-production level between the offeror and the beneficiary.

The importance of the research comes from the fact that each beneficiary of educational services can give essential information on the factors that form the stages of co-production. Thus, the questionnaire revealed information on how co-involvement, co-planning, comanagement of time, co-learning, and co-assessment are perceived and the connection between education and performance.

The questionnaire used consisted of 15 questions, of which ranked-choice questions, open questions and closed questions, including identification questions.

In question Q1: "Does co-production in education involve a greater mutual use of resources by teachers and students in order to enhance performance?"

\section{DE GRUYTER} OPEN
Timisoara Journal of Economics and Business | ISSN: 2286-0991 | www.tjeb.ro Year 2017 | Volume 10 | Issue 1 | Pages: 35-50 
Jivan, A., \& Barabas, M. (2017).

The coordinates of co-production in the educational services system

- 61 people responded that they agree;

- 16 people agreed completely.

According to data obtained (Figure 1), we noted that there was no neutral or negative answer, which indicates the importance that beneficiaries of educational services attach to joint, mutual management of resources with offerors.

\section{Co-production in education involves a greater mutual use of resources by} teachers and students in order to enhance performance

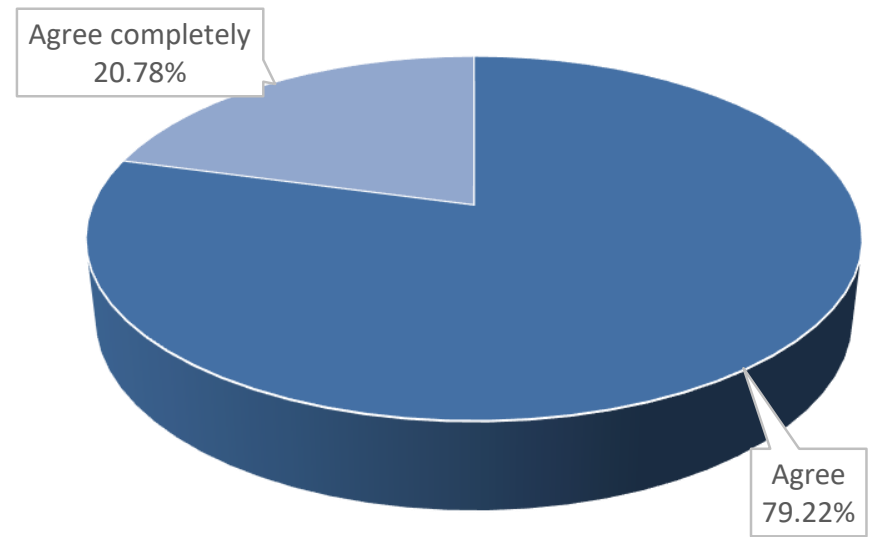

Figure 1. Co-production in education involves a better mutual use of resources

Source: Barabaș, M., 2017

On what school performance means $(\mathrm{Q} 2)$ :

- 42 (35 NO) respondents agree that performance in school means teacher effectiveness (Q2.1, Figure 2);

- 29 (48 NO) respondents believe that performance in school means student effectiveness (Q2.2);

- 37 (40 NO) respondents believe that performance in school means the degree of passing exams by students (Q2.3);

- 43 (34 NO) respondents believe that performance in school means the satisfaction of students on knowledge assimilated (Q2.4);

- only 4 respondents believe that performance in school means school competitiveness (Q2.5);

- 37 respondents (40 NO) agree that performance in school means results subsequently obtained by students, or in the future, at the university and in the workplace (Q2.6).

\section{DE GRUYTER} OPEN 
Jivan, A., \& Barabas, M. (2017).

The coordinates of co-production in the educational services system

The majority of YES was obtained from the statement that combines performance in school with the effectiveness of teachers, which shows that beneficiaries of educational services positively appreciate the presence and professionalism of teachers.

Also, performance is associated with the satisfaction of students on knowledge assimilated, indicating that, as in the trading system where consumers want to buy advantages, in the education sector, students want to obtain useful experiences, corresponding to the expectations specific to training/education.

In question Q3, on the first three things that come to mind when thinking of teacher-student cooperation, most respondents answered with: communication, mutual respect, working together (Figure 2). These are concrete forms by which co-involvement, co-planning and comanagement of time take place.

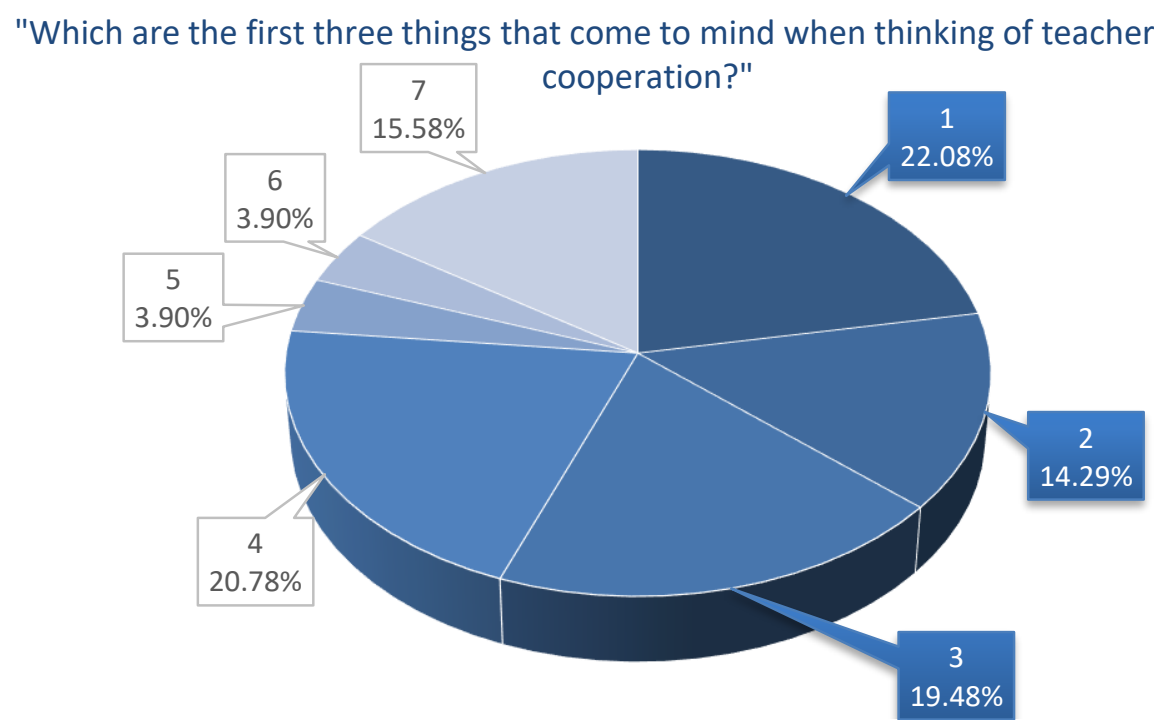

Figure 2. First three things that come to mind when thinking of teacher-student cooperation: 1.Communication; 2. Mutual respect; 3. Working together

Source: Barabaș, M., 2017

The graph resulted from question Q4 shows that almost 95\% of respondents believe that their performance depends on the optimal communication with the offerors of educational services.

DE GRUYTER OPEN
Timisoara Journal of Economics and Business | ISSN: 2286-0991 | www.tjeb.ro Year 2017 | Volume 10 | Issue 1 | Pages: 35-50 
Jivan, A., \& Barabas, M. (2017).

The coordinates of co-production in the educational services system

Question Q5 includes several sub-questions (9), each with a Lickert scale, containing ratings from "not at all" to "very much". On the success of classes, the role of offerors of educational services is recognised as very high. In Q5.1, 75\% of respondents answered that the manner in which teachers prepare and direct the teaching, learning and assessment activity is important. The nonverbal and paraverbal languages are also considered essential. Students learn not only what teachers say, but they copy their gestures, facial expressions, attitudes. It is known that the final impression is determined, ultimately, by nonverbal language, and that, in communication, the verbal message makes only a $10 \%$ impression on the interlocutor.

Maintaining confidence strengthens cooperation, as $75.32 \%$ of students responded.

But co-production would be impossible without feedback, as shown in the survey results. Contrary to expectations, the students believe that even negative feedback is important for the success of classes. When provided at the right time and in the appropriate manner, critique triggers a high degree of motivation. Through their responses, students show that they understand and agree that without awareness of the mistakes made they would not have a way in which to improve how they act.

The professional interaction between students and teachers (Q6) is considered by most respondents a necessary condition to improve attitudes towards learning and increase selfesteem.

To obtain performance, the interaction between teachers and students is necessary, but not sufficient. When asked about the top three factors they associate with performance (Q8), students answered: motivation, (team and individual) work and wellbeing/future.

In Q7, the majority of respondents (97.40\%) believe that, to enhance school performance, student-teacher cooperation is important.

When asked "does student participation in teaching, learning and assessment ensure the success of both parties", the responses are, in percentage of $84.42 \%$, positive. To justify their answer, most respondents believe that both the teacher and the student can learn from each other and also that the impact of participation is beneficial for both parties.

In Q9 on the relationship between school performance and future job performance, most answers were positive, considering the relationship very relevant.

DE GRUYTER OPEN
Timisoara Journal of Economics and Business | ISSN: 2286-0991 | www.tjeb.ro Year 2017 | Volume 10 | Issue 1 | Pages: 35-50 
Jivan, A., \& Barabas, M. (2017).

The coordinates of co-production in the educational services system

Logically, beneficiaries of educational services regard knowledge assimilated during school years as a long-term acquisition. It is also recognised that skills formed as a student will accompany them in all the activities throughout life.

\section{Verification of hypotheses. Interpretation of data}

We conducted an internal consistency and reliability analysis for all involved scales. After eliminating the variables with low loadings $(<0.5)$ on their respective factor, we let all the scales with an acceptable level of alpha Cronbach $>0.6)$.

The operationalisation of co-production by the six conceptual components mentioned (coinvolvement, co-planning, co-management of time, co-learning, co-assessment and reciprocal adjustment) enables the specification of observable behaviours. The issues raised concretely in our study on samples were: "what is cooperation?", "how is participation perceived?", "to what extent and how does the behaviour of the beneficiary of educational services change over time under the influence of the interaction with the offeror?"

To verify the hypotheses, we used the numerical and percentage statistical interpretation, the statistical mean interpretation, the analysis of frequencies (Table 1) and the analysis of the correlations between the variables.

Table 1 Descriptive Statistics

\begin{tabular}{lllc}
\hline & $\mathbf{N}$ & Man & $\begin{array}{c}\text { Std. } \\
\text { Deviation }\end{array}$ \\
\hline $\begin{array}{l}\text { Co-production in education implies a greater mutual use of } \\
\text { resources }\end{array}$ & 77 & 3.21 & .408 \\
\hline Performance in school means teacher effectiveness & 77 & .55 & .501 \\
\hline Performance in school means student effectiveness & 77 & .38 & .488 \\
\hline $\begin{array}{l}\text { Performance in school means the degree of passing exams } \\
\text { by students }\end{array}$ & 77 & .48 & .503 \\
\hline $\begin{array}{l}\text { Performance in school means the satisfaction of students } \\
\text { on knowledge assimilated }\end{array}$ & 77 & .56 & .500 \\
\hline $\begin{array}{l}\text { Performance in school means school competitiveness } \\
\text { Performance in school means results subsequently } \\
\text { obtained by students, or in the future, at the university and } \\
\text { in the workplace }\end{array}$ & 77 & .48 & .503 \\
\hline $\begin{array}{l}\text { Student performance is influenced by the optimal } \\
\text { communication between them and the teachers }\end{array}$ & 77 & 3.35 & .580 \\
\hline $\begin{array}{l}\text { For the success of classes, an important role is played by } \\
\text { maintaining confidence }\end{array}$ & 77 & 4.01 & 1.006 \\
\hline
\end{tabular}

DE GRUYTER OPEN
Timisoara Journal of Economics and Business | ISSN: 2286-0991 | www.tjeb.ro Year 2017 | Volume 10 | Issue 1 | Pages: 35-50 
Jivan, A., \& Barabas, M. (2017).

The coordinates of co-production in the educational services system

The relationship cooperation-coproduction was analysed through a set of targeted questions, relevant aspects including general notions on co-production, the first three things suggested by the idea of cooperation, the association between performance and certain items, the relationship seen between education, school performance and performance as a way of life. A Lickert scale was used to investigate attitudes towards interaction, cooperation and performance.

Table 2 Hypothesis testing results

\begin{tabular}{cccc}
\hline Hypothesis & Pearson Correlation & Sig (2 tailed) & Result \\
\hline $\mathrm{H} 1$ & .266 & .000 & Sustained \\
\hline $\mathrm{H} 2$ & .321 & .000 & Sustained \\
\hline $\mathrm{H} 3$ & .406 & .000 & Sustained \\
\hline
\end{tabular}

All research hypotheses were found to be valid, with Sig 2 tailed level of .000 , which shows that there is statistically significant correlation between our variables. The relationship is positive $(26,6 \% ; 32,1 \%$; $40,6 \%)$ which means there is a strong relationship between the variables. This means that changes in one variable are strongly correlated with changes in the second variable.

11: The cooperation between the offeror and the beneficiary of educational services is a prerequisite for co-production.

The survey results show that beneficiaries of educational services perceive cooperation as communication, respect, working together, which, over time, leads to wellbeing and a better future. Given that the cooperation between the offerers and the beneficiaries of educational services influences the latter's attitudes towards learning and their self-esteem, it follows that, working together; their axiological adaptation takes place, according to the values and knowledge conveyed to them. It is the very accomplishment of the educational ideal modelling the personality type desired by society.

12: The co-production between the offeror and the beneficiary of educational services contributes to the long-term performance of the beneficiary.

Answers to the question on the first three factors associated with performance are consistent with our hypothesis. Motivation is conveyed from teacher to student through continuous interaction and cooperation, serving to design the future based on the values and traditions communicated. We call this trend "sensitivity" of the educational services beneficiaries to the positive interaction between the bidder and beneficiary.

\section{DE GRUYTER} OPEN
Timisoara Journal of Economics and Business | ISSN: 2286-0991 | www.tjeb.ro Year 2017 | Volume 10 | Issue 1 | Pages: 35-50 
Jivan, A., \& Barabas, M. (2017).

The coordinates of co-production in the educational services system

13: Organisational performance is dependent on the co-production level between the offeror and the beneficiary.

Data analysis reveals the lack of the sense of belonging to the organisation, given that a majority of almost $95 \%$ of the students do not believe that school performance also means competitiveness (school competitiveness). But, coproduction level means the intensity and the qualitative level of coproduction. Instead, about $55 \%$ of respondents believe that future job performance depends on the performance they had as students, considering this report as directly proportional.

The results of the research based on samples signals the conditioning of the existence of coproduction by cooperation, and therefore a strong positive association between cooperation and the existence of co-production, but also between co-production and the beneficiary's long-term performance.

\section{Limitations of the study}

In the research conducted, the main problem that we encountered was the refusal of some school organisation to grant us the permission to apply the questionnaire. Personal travel to some towns was necessary, as people are more open to cooperate when there is a direct, personal contact.

Also, the answers of the interviewees have some limits due to the influence of certain factors: the topic addressed by the questionnaire, the novelty of certain concepts, the time required for the survey. In most cases, the time for filling in the questionnaire was of one hour for about 25 people, which also included an explanation of unknown or ambiguous terms.

An important aspect is the omission of the term "co-production" in the questionnaire (used only in question Q1) due to its poor usage in everyday life and, therefore, the desire not to create confusion among respondents. Its meaning was shaped along the way from how other questions were formulated.

\section{Conclusions and future works}

By using a survey conducted in three representative high schools in the country, we aimed to illustrate how beneficiaries of educational services understand cooperation in the teachinglearning process, and the gradual introduction of certain questions has led to discerning how cooperation and co-production are related. The data supports the idea that, in cooperation, the offerer and the beneficiary's resources are pooled in a joint participation, and that, in co-

DE GRUYTER OPEN
Timisoara Journal of Economics and Business | ISSN: 2286-0991 | www.tjeb.ro Year 2017 | Volume 10 | Issue 1 | Pages: 35-50 
Jivan, A., \& Barabas, M. (2017).

The coordinates of co-production in the educational services system

production, together with cooperation, the mutual adaptation of behaviours, knowledge, objectives, performance occurs in view of common educational goals.

The study focused on the co-production between the offeror and the beneficiary of educational services. The results indicate that teacher-student interaction in various stages of teaching, learning and assessment is a necessary prerequisite for the existence of coproduction. In terms of performance, teacher effectiveness and the satisfaction of students on the knowledge assimilated seem promising, which shows that education is seen as a service that people acquire for its advantages. In terms of co-production, the management of time, material resources, especially psychological, are ways to implement the provision of educational services.

The paper describes a meaning of co-production which can be used in the education sector to describe the various forms of correlation, cooperation and mutual adaptation of resources, behaviour, attitudes, expectations and values of the offeror and the beneficiary of educational services.

\section{References}

Andreassen, T., Gustafsson, A., \& Gebauer H. (2010). Co-production: A Fair-Weather syndrome? Journal of the academy of Marketing Science.

Baqer, S.M. (2006). The value of Customer Co-production in Developing New Products. The University of Texas Arlington, visited at www.citeseerx.ist.psu.edu

Bateson, John E. G. (2000). Perceived control and the service experience. In Handbook of services marketing and management, T. Swartz and D. lacobucci, Eds. Thousand Oaks, Calif.: Sage, 127-144.

Becker, G.S. (1997). Capitalul uman. București: All.

Bendapudi, N., \& Leone, R. P. (2003). Psvchological Implications of Customer Participation in Co-Production. Journal of Marketing 67(1), 14-28.

Bettencourt, L. A. (1997). Customer Voluntary Performance: Customers as Partners in Service delivery. Journal of Retailing, 73 (3), 383-406.

Bhappu, A. D., \& Schultze, U. (2006). The role of relational and operational performance in business-tobusiness customers' adoption of self-service technology. Journal of Service Research, 8(4), 372-385.

Dabholkar, P. A. (1990). How to Improve Perceived Service Quality by Increasing Customer Participation. In B. J. Dunlap, editor, Developments in Marketing Science XIII.

Etgar M. (2008). Ways of Engaging Consumers in Co-production. Technology Innovation Management Review, visited at www.timreview.ca.

Grönroos, C. (2007). Service management and marketing: Customer management in service competition (3rd ed.). Chichester: Wiley.

Jivan Al. (2014). Productivité et servicité. Economies et Sociétés, No.4/2014, Cahiers de I'ISMEA, No 4/2014 (Série "Economie et Gestion des Services » EGS No 15, Avril 2014), pp 579-599.

DE GRUYTER OPEN
Timisoara Journal of Economics and Business | ISSN: 2286-0991 | www.tjeb.ro Year 2017 | Volume 10 | Issue 1 | Pages: 35-50 
Jivan, A., \& Barabas, M. (2017).

The coordinates of co-production in the educational services system

Schultze, U., \& Bhappu. A.D.. (2005). Incorporating Self-Serve Technology into Co-Production Designs. International Journal of e-Collaboration, 1/4, 1-23.

Terblanche, Nic., S. (2014). Some theoretical perspectives of co-creation and co-production of value by customers. Retrieved at www.actacommercii.co.za 